\title{
BARBITURATES IN OBSTETRICS: EFFECTS ON THE NEWBORN $*$
}

ROLAND DUChesNe, M.D

Armand Lamontagne, M.D.

JEAN LACASSE, M.D.
Bernard PARAdis, M.D.

PaUl SiRois, M.D.

ANDRÉ BERNIIR, M.D. ${ }^{*}$

The barbiturates are employed in obstetrics with the objective of rendering the patient quiet and drowsy so that she will sleep between pains and not remember the ordeal but nevertheless remain sufficiently conscious to assist in the delıvery. Therr disadvantages, especially when administered intravenously or by the rectal route, have been emphasized frequently and one would think that there is little need for reiteration However, some obstetricians still administer large doses of barbiturates to obtain basal anaesthesia and analgesia.

We practse in one part of this country where barbiturates are still widely used in obstetrics, both by intravenous and rectal administration. The'Department of Anaesthesiology was aware of the physiological changes these drugs could produce on the newborn. To satisfy our curiosity, we first made no efforts to modify the procedure already established, and, second, recorded statistical data concerning the effects on the newborn

All the cases included in this series were followed by a member of our anaesthesia staff All the patients anaesthetized by nurses or interns were excluded. We also excluded the pathological cases in which the condition of the newborn was possibly due to the obstetrical trauma. The cases in this series totaled 2605, which, when classified under the type of drug combination used to produce analgesia, give the following figures.

Demerol and hyoscine-1040 cases

Demerol, hyoscine and an oral barbiturate- 562 cases

Demerol, hyoscine and rectal Pentothal-561 cases

(Average dose of Pentothal 15 grammes)

Barbiturates were also used intravenously in 133 cases (mostly for Caesarian section). 'Somnifine or barbituric diethyl acid isopropyl, barbituric acid diethylamine was used in 55 cases intravenously durnng labour

General anaesthesia was given in 90 per cent of the cases, consisting of $\mathrm{N}_{2} \mathrm{O}+\mathrm{O}_{2}$ or $\mathrm{C}_{3} \mathrm{H}_{6}+\mathrm{O}^{2}$. Spinal anaesthesia and caudal block accounted for the other 10 per cent of the cases.

For statistical purposes, we have considered three types of conditions in the newborn:

1. A breathing time of 1 minute or less.

2. A breathing time of between 1 to 5 minutes with the help of reanimation measures.

'Presented at the Annual Meeting of the Canadian Anaesthetists' Society, Toronto, June 20,21 and 22,1955

* Authors from the Department of Anaesthesiology, St François d'Assise Hospital, Quebec City, Canada. 
3. A breathing tme of more than 5 munutes with all possible resuscitative measures.

Reanimation consisted first of aspirating the secretions from the upper respiratory tract, after which a mechanical resuscitator was used, associated with endotracheal intubation when it was necessary. l.t was also routine to empty the newborn's stomach.

Among the various types of drug combinations used to produce analgesia, association no. I (Demerol $100 \mathrm{mg}$. and hyoscune gr 1/150) has seemed to influence the breathing time to a less degree than the others. It is usually said ath Demerol and hyoscine untoward effects on the mother and the child are absent. Nevertheless we have found that reanimation was necessary in 14 per cent of the cases. The effect on the newborn was greater when this combination was repeated every two or three hours or when a single dose was given within one hour of the delivery. In one case a syncopal reaction occurred in a patient, with sweating, hypotension, and bradycardıa shortly after an injection of meperidine. The mother gave birth to at dead baby 45 minutes after this syncopal reaction. In our opinion the newborn's condition was secondary to the pronounced fall in the mother's blood pressure.

Combination no. 2 consisted of Demerol $100 \mathrm{mg}$. and hyoscine gr. 1/150 and a barbiturate, usually secobarbital (Seconal) or pentobarbital sodium (Nembutal), given by mouth. The usual dosage for the barbiturate was $1^{1 / 2}$ grain. The barbiturate was seldom given within two hours of expected delivery. Most people consider barbiturates given orally a satisfactory method of obtaining good amnesia and safe analgesia. Nevertheless the percentage of reanimation, which was less than 15 per cent when Demerol and hyoscine alone were used, increased to 25 per cent with the addition of a barbiturate. This, I think, has a great significance and also a great importance, because short-acting barbiturates are frequently employed in various combinations with other agents, particularly with Demerol and hyoscine.

Combination no 3 consisted of Demerol and hyoscine in the usual oroportion, given subcutaneously, and a short-acting barbiturate, usually Pentothal, given by the rectal route. The Pentothal was given in a dose of $1 \frac{1 / 2}{\text { gram, in a }}$ $2 \frac{1}{2}$ per cent solution, and was seldom given within two hours of expected delivery. This association of Demerol, hyoscine, and rectal Pentothal has procured almost complete amnesia to the mothers, and a very light anaesthesia needed to be added for the delivery. However it was found to be the most disastrous for the child. More than 35 per cent of the newborns needed reanimation. In many instances the reanimation was long and laborious, requiring sometimes five minutes and more

In three instances when the barbiturates had been given within two hours of the delivery the normal-term babies were dead at birth. The post-mortem on each failed to reveal any abnormality or obstetrical trauma. It was believed that the barbiturate should most likely be blamed

Intravenous injection of barbiturates (specially Pentothal) was used 140 times, mostly for Caesarian sections. The dose never exceeded $250 \mathrm{mg}$. followed by $\mathrm{N}_{2} \mathrm{O}+\mathrm{O}_{2}$ and a relaxing agent. An average of five minutes elapsed between 
the injection of the barbiturate and the clamping of the cord. Premedication for Caesarian section consisted of atropine only. The percentage of asphyxiated babies was similar to the one observed when the barbiturate was given by the rectal route, with the exception that the asphyxia was! not quite as severe. Not a single newborn was lost. Such a result is due in part to the fact tha: a small amount of Pentothal is injected not more than five minutes before he clamping of the cord and it is due also to the absence of obstetrical trauma.

Another barbiturate called "Somnifene" (diethyl barbituric acid) was given 55 tumes intravenously during labour. Its effect in prolonging the breathing time was striking, the reanmation rate being over 40 per cent, the reanimation was difficult in most of these cases. One of these babies was very cyanotic and in spite of adequate resuscitation he died six hours later. There had been no obstetrical trauma and the post-mortem revealed no malformation of any kind. It was believed that the hypoxia began in utero as in the previous cases, the mother's depressed respiration creatng a state of hypoxia which secondarily affected her child. The harmful effects of these drugs was most evident when a potent anaesthetic like cyclopropane was used. There were fewer depressed babies when nitrous oxide or spinal was used.

The incidence of reanimation was greater among primipares than among multipares, and this is surely related to the longer duration of the primipare's labour, with concomitant use of larger amounts of depressing drugs.

N-Allinormorphine or Nalline was used 35 times both , for patients who received Demerol and hyoscine and for those who received Demerol and hyoscine and Pentothal. It has seemed to aggravate the respiratory depression in those already touched by the barbiturates. The number of cases in which it was used is not great enough to allow definite conclusions to be drawn.

One need not be su-prised by the deleterious effects of the barbiturates on the foetus when one corsiders the mode of action, and the facility with which barbiturates cross the placental barrier. Not only the respiration in the newborn is retarded by all central depressants given to the mother but the respiratory mechanism of the mother may also be affected adversely by the use of barbiturates, with conseq ient foetal hypoxia.

Adequate resuscitaive measures account for the mortality rate not being greater than it has been, but even then some stillbirths of normal-term babies cannot be understood except by the theory of foetal hypoxia. Even with good resuscitative measures the foetal mortality rate was above what is considered the normal in our days.

\section{CURARE}

During these last four years we have employed decamethonium bromide in many obstetrical cases, both to provide adequate muscular relaxation and to allow smaller amounts of anaesthetics to be given. Decamethonium bromide was used 354 times for vaginal deliveries. The patient is usually anaesthetized with cyclopropane and between 2 and $3 \mathrm{mgm}$. of Syncurine are injected before the forceps are applied.

For Caesarian section anaesthesia is induced with Pentothal (usually $200 \mathrm{mg}$.), 
the induction being delayed until the obstetrician is ready to make the incision, and Syncurine (usually $4 \mathrm{mg}$.) is given immediately after the patient has lost consciousness. $\mathrm{N}_{2} \mathrm{O}+\mathrm{O}_{2}$ is then given untl the baby is born

When we started to use decamethonum in obstetrical anaesthesia it was our belief, and that of others, that it had no effect on the newborn. Pettunger and Morris, exכermmentung in dogs $s_{2}$ reported that placental transmission of D-tubocurarine aad been demonstrated after injection of large doses of the drug into the uterne artery. They clamed, however, that the small amounts of the drug ordinarily employed in obstetrics were without significant effects on human infants. Our experience, however, with nearly 500 cases in which $\mathrm{C}_{10}$ was used is in contradiction with what we thought, and what has been reported on the subject.

As we said previously, for a total of 691 mothers receiving Demerol and hyoscine for analgesia the incidence of apnoea in the newborn was 15 per cent For 254 patients receiving the same dose of Demerol and hyoscine the incidence of asphyxıa in the newborn rose to 27 per cent when decamethonium bromide was injected into the mother, a difference of 12 per cent.

So, with identical analgesia, reanimation has been done 12 per cent more often when a relaxing agent like $\mathrm{C}_{10}$ had been given to the mother It is our belief that more expermments will have to be made regarding the effects of curarising agents on the newborn.

\section{SUMMARY}

1. The association of Demerol and hyoscine, which is largely used, has been the drug combination least detrimental to the foetus. It can be detrimental when it is repeated or used within one hour of the delivery Syncopal reactions are also possible which secondarily affect the child.

2. Barbiturates used in large doses, whether it be intravenously or rectally, have a strikng or marked depressing effect on the newborn. A small amount (not over $250 \mathrm{mg}$ of a $2 \frac{1}{2}$ per cent solution of Pentothal) given intravenously not sooner than 5 minutes before the birth (as used in Caesarian sections) has a less deleterious effect than a larger dose given rectally.

3 The addition of a potent general anaesthetic like cyclopropane enhanced the danger of foetal asphyxia.

4. Spinal anaesthesia or $\mathrm{N}_{2} \mathrm{O}$ alone or supplemented with trilene should be substituted whenever possible.

5. Decamethonium bromide, in spite of some reports, has seemed to affect the newborn

6. Asphyxia neonotorum and its possible sequelae on the central nervous system is so often produced by barbiturates that their use in obstetrics should be restricted to a minimum. To expect the barbiturates to produce complete amnesia and analgesia for a number of hours and to have no ill effects on the baby is asking too much. Any hospital that wishes to diminish the neonatal mortality rate should, as a first step, banish the barbiturates, especially those given by intravenous and rectal administration, and be careful with curarising agents. These measures are already being applied in our medical group with undeniably good results. 
RÉSUMÉ

Nous avons voulu prouver une fors de plus, après tant d'autres, l'effet désastreux des barbituriques sur le nouveau-né en prenant comme guide la fréquence de la réanimation fotale.

Un relevé de 2605 cas d'anesthésies obstétricales exécutées par le Service d'Anesthésiologie de l'Hôpital St-Françoıs d'Assıse nous a donné les précisions suivantes:

1. Le démérol $100 \mathrm{mgm}$ avec l'hyoscine $1 / 150$ associés ou non à un barbiturique par voie orale, administrés ou injectés à la mère plus d'une heure avant l'expulsion, ont nécessité la réanımation du fœtus dans une proportion de 15 pour-cent.

2 L'action des barbiturnques par vore rectale s'est avérée funeste à tel point qu'au delà de 35 pour-cent cles fœetus durent être réanimés.

3. Le pourcentage de la reanimatión fœetale s'est élevé à 50 pour-cent après l'mjection intravemeuse de somnifène. Une mort fœtale par hypoxie lui est attribuable

La rachı-anesthésie a été moins préjudicıable à l'enfant que les anesthésiques généraux tels que le cyclopropane et l'éther.

L'effet de ces derniers ajouté à celuu des barbituriques a amené un pourcentage élevé de réanimation chez les nouveau-nés

Malgré l'opinion généralement établie les curares tel quẹ le $\mathrm{C}_{10}$ ont semblé affecter la respiration des nouveau-nés. $\mathrm{S}_{1}$ on prend un nombre déterminé de parturientes ayant reçu pendant le travail les mêmes médıcaments on trouve un pourcentage de réanımation fœtale plus élevé chez celles à qui on a injecté, par voie intra-vemeuse avant l'expulsion, de 2 à $3 \mathrm{mg}$. de syncurine.

L'impression générale qui se dégage est la suivante: les barbituriques par voie intra-veineuse ou rectale à cause de leur effet nocff sur le nouveau-né n'ont pas leur place en obstétrique. Tout hôpital quı a à cœur de diminuer son taux de mortalité fœetale doit bannir les barbituriques donnés par voie intraveineuse et par voie rectale et être prudent avec les substance curarisantes.

Ces mẹsures ont déjà été prises dans notre milieu avec des résultats indéniables.

\section{REFERENCES}

1 Toveld, R M Anesthesia Useful Agents and Methods for Gynecological and Obstetrical Procedures, in Curtis, A H. Obstetrics and Gynecology, vol, 3, chap. 102, pp. 989 1079 Phladelphia. W B Saunders Company (1933)

2 Hellman, L. M \& Eastmary, N J. et al. Sodium Pentothal Anesthesia in Obstetrics Am J. Obst \& Gyne. 48 \&51 (1944)

3 Lull, C. B. \& Hingson, R A. Control of Pain in Childbirth 2nd ed, Philadelphia. J B. Lippincott Company (1944)

4 Bundesen, Herman N Effective Reduction of Needless Hebdomadal Deaths in Hospitals Chicago 